\title{
Comparison of nine DNA extraction methods for the diagnosis of bovine tuberculosis by real time PCR
}

\author{
Comparação de nove métodos de extração de DNA para diagnóstico \\ de tuberculose bovina por PCR em tempo real
}

\begin{abstract}
André Moura ${ }^{\mathrm{I}}$ Mikael Arrais Hodon ${ }^{\mathrm{I}}$ Paulo Martins Soares Filho ${ }^{\mathrm{I}}$ Marina de Azevedo Issa Ana Paula Ferreira de Oliveira ${ }^{I}$ Antônio Augusto Fonseca Júnior ${ }^{{ }^{*}}$
\end{abstract}

\section{ABSTRACT}

Bovine tuberculosis is an infectious disease with a high impact on the cattle industry, particularly in developing countries. PCR is a very sensitive method for detection of infectious agents, but the sensitivity of molecular diagnosis is largely dependent on the efficiency of the DNA extraction methods. The objective of this study was to evaluate DNA extraction methods for direct detection of Mycobacterium bovis in bovine tissue. Nine commercial kits for DNA extraction were evaluated when combined with two real time PCRs. The DNeasy Blood \& Tissue Kit from QIAGEN showed better performance and sensitivity followed by the DNA Mini Kit RBC and FTA Elute Micro Card. Results suggested that, even when the analytical sensitivity of the $q P C R$ is very high, the extraction method can influence the diagnostic sensitivity.

Key words: bovine tuberculosis, DNA extraction, real time PCR.

RESUMO

A tuberculose bovina é uma doença infecciosa com um alto impacto na pecuária, particularmente em países em desenvolvimento. A PCR é um método muito sensivel para a detecção de agentes infecciosos, mas a sensibilidade do diagnóstico molecular é em grande parte dependente da eficiência dos métodos de extração de DNA. O objetivo deste estudo foi avaliar métodos de extração de DNA para deteç̧ão direta de Mycobacterium bovis em tecido bovino. Nove kits comerciais para extração de DNA foram avaliados, quando combinados com duas PCRs em tempo real. O Kit Dneasy Blood \& Tissue da Oiagen apresentou melhor desempenho e sensibilidade, seguido dos kits DNA Mini RBC e FTA Elute Micro Card (protocolo modificado com digestão enzimática prévia). Os resultados sugerem que, mesmo quando a sensibilidade analitica do qPCR é muito elevada, o método de extração pode influenciar na sensibilidade de diagnóstico.

Palavras-chave: tuberculose bovina, extração de DNA, PCR em tempo.

\section{INTRODUCTION}

Bovine tuberculosis (bTB) is an infectious disease with a high impact on the cattle industry, particularly in developing countries. It is characterized by the development of nodular granulomatous lesions, predominantly located in the respiratory tract and bronchial and mediastinal lymph nodes. The economic losses are related to the direct impact of infection due to reduced weight gain, decreased milk production and condemnation of carcasses or indirect losses as the depreciation of meat price due to sanitary barriers (BRAZIL, 2006; HEINEMANN et al., 2008).

Lesions found at post-mortem examinations can be confirmed by bacterial isolation, the gold standard method for detection of Mycobacterium bovis. However, this technique is laborious and time consuming and may require months to reach its conclusion, which slows the development of health programs, which aim to control and eradication of the disease (De La RUE-DOMNENECH et al., 2006). Thus, to reduce the time of diagnosis of tuberculosis in cattle, new molecular methods are proposed.

The polymerase chain reaction (PCR) is a very sensitive method for the detection of infectious agents, including the evaluation of animals in epidemiological surveys (YOON et al., 2005). The speed of the methodology can be increased by using real-time PCR (qPCR) which, besides providing

\footnotetext{
'Laboratório Nacional Agropecuário de Minas Gerais, Av. Rômulo Joviano, CP 50, 33600-000, Pedro Leopoldo, MG, Brasil. E-mail:
} antonio.fonseca@agricultura.gov.br. "Corresponding author. 
better precision, reproducibility and quality control in the process, reduced contamination and enabled the analysis of a large number of samples in a shorter period of time (SALES et al., 2013).

The sensitivity of molecular diagnosis is largely dependent on the efficiency of the DNA extraction methods (NAKATANI et al., 2004). Isolation of bacterial DNA in tissues is a highly complex procedure, mainly because of the low concentration of microorganisms in the tissue sample and the presence of large amounts of contaminant genetic material, making difficult to obtain high quality DNA (BURGGRAF \& OLGEMÖLLER, 2004). Currently, there are several commercial kits for the extraction of bacterial genetic material directly from tissues. Although some studies have shown a significant variation in the sensitivity of PCR according to the extraction method used, there is no definitive view regarding the best method of extraction of DNA from $\boldsymbol{M}$. bovis in bovine tissue samples (YOSHIKAWA et al., 2011). The objective of this study was to evaluate nine DNA extraction methods for the direct detection of $\boldsymbol{M}$. bovis in bovine tissue.

\section{MATERIALS AND METHODS}

\section{Sample preparation}

All samples were derived from cattle carcasses in slaughterhouses inspected by the Serviço de Inspeção Federal (SIF) and sent to the official diagnosis facility in Brazil. Tissues contained granulomatous lesions suggestive of bTB in retropharyngeal, mediastinal and mesenteric lymph nodes, liver and lung fragments. A small fraction of each sample was extracted in a biological safety cabinet Class II A and aliquoted into $2 \mathrm{ml}$ tubes containing $500 \mu \mathrm{L}$ of ATL buffer (Qiagen, Germany). Enzymatic digestion was done adding $50 \mu \mathrm{L}$ of Proteinase $\mathrm{K}$ to each sample and incubating overnight at a temperature of $56.5^{\circ} \mathrm{C}$. Subsequently, the samples were inactivated at $87.5^{\circ} \mathrm{C}$ and subjected to DNA extraction.

\section{DNA extraction}

There were five rounds of testing, in which seventy different randomly chosen samples were assessed. The tests were performed in rounds, due to insufficient volume of each sample being available for simultaneous evaluation of all extraction methods. In each round, the samples were extracted with two or three different commercial kits. The kit with the best performance in the first round was compared to other kits in the next round and so on.
The first round of tests comparing the extraction of 70 samples with three commercial extraction kits: Maxwell 16 (Promega, USA), DNeasy Blood \& Tissue kit (Qiagen, Germany) and Cador Pathogen (Qiagen, Germany), using initial volumes for extraction of $400 \mu \mathrm{L}$ and $200 \mu \mathrm{L}$. The second round of tests compared the extraction of 70 samples with another three commercial extraction kits: NucleoSpin TriPrep (Macherey-Nagel, Germany) DNA Blood \& Tissue kit (Qiagen, Germany) and innuPREP DNA Mini Kit (Analytik Jena, Germany). The third round of tests compared the extraction of 70 samples with three further commercial extraction kits: Wizard Genomic DNA Purification Kit (Promega, USA), DNA Blood \& Tissue kit (Qiagen, Germany) and Genomic DNA Mini Kit (Real Biotech Corporation, $\mathrm{RBC}$, Taiwan). The fourth round of tests compared the extraction of 70 samples with two more commercial extraction kits: DNA Blood \& Tissue kit (Qiagen, Germany) and MagNA Pure LC DNA Isolation Kit II (Roche, Germany) using equipment Magna Pure (Roche, Germany). The fifth round of tests compared the extraction of 70 samples with two additional commercial extraction kits: DNA Blood \& Tissue kit (Qiagen, Germany) and Whatman FTA Elute cards.

All methods and extraction kits tested followed the extraction protocols recommended by the companies without modification, except for the extraction method used for the Whatman FTA Elute Cards, in which there was the following adaptation: cards were impregnated with $20 \mu \mathrm{L}$ of each sample after enzymatic digestion and left at room temperature atmosphere for three hours to dry. After drying, a Harris Uni-Core ${ }^{\mathrm{TM}}$ Micro-3mm punch was used to cut a disk with diameter of $3 \mathrm{~mm}$ from on each card. Resultant disks were immersed in $500 \mu \mathrm{L}$ of sterile DEPC water. Then, each sample was homogenized three times for five seconds by vortexing. Subsequently, using a micropipette, all water was removed. Each sample was centrifuged for five seconds and the resulting liquid was discarded. $50 \mu \mathrm{L}$ of sterile DEPC water was added in each sample and incubated at a temperature of $95^{\circ} \mathrm{C}$ for 30 minutes. After this process, the samples were quickly homogenized, followed by centrifugation for 30 seconds in order to separate the matrix from the liquid containing the purified DNA. The microtubes containing the final DNA were placed in a refrigerator at $-20^{\circ} \mathrm{C}$ until use.

Due to the high initial DNA concentration obtained in the Genomic DNA extraction kits Mini Kit and Wizard ${ }^{\circledR}$ Genomic DNA Purification Kit, there was need for a serial dilution of $10^{-1}, 10^{-2}, 10^{-3}$ in 
sterile DEPC water. After the extractions were carried out at different concentrations, it was concluded that the best dilution for performing qPCR was 10-3 whose mean concentration was $100 \mathrm{ng} \mu \mathrm{L}^{-1}$.

PCRs

Extracted DNA was subjected to qPCR on the unit QuantStudio 7 Flex $^{\mathrm{TM}}$ Real-Time PCR System (Life Technologies, USA) and used in a $25 \mu \mathrm{L}$ reaction containing the following reagents: $3 \mu \mathrm{L}$ DNA, $4.0 \mu \mathrm{L}$ RNase free water, $12.5 \mu \mathrm{L}$ of RealQ PCR $2 \times$ Master Mix (Amplicon, Denmark), $4.0 \mu \mathrm{L}$ of $\mathrm{MgCl}_{2}$ (25nM). Primers and probes for the two PCRs used are described in table 1 . The following cycling regime was used: $50^{\circ} \mathrm{C}$ for $2 \mathrm{~min}, 95^{\circ} \mathrm{C}$ for $10 \mathrm{~min}$ and 50 cycles at $95^{\circ} \mathrm{C}$ for $15 \mathrm{~s}$ and $60^{\circ} \mathrm{C}$ for $1 \mathrm{~min}$. Positive samples were those that had amplified Cq's less than or equal to 42.0. All samples amplified with Cq's above this value were considered negative.

The positive control for all PCRs were the reference strain of $\boldsymbol{M}$. bovis AN5 (CANEVARI CASTELÃO et al., 2014). In addition to the positive controls, all tests relied on negative control for DNA extraction and negative control to check contamination of PCR reagents.

Statistical analysis

McNemar test with 5\% significance level was used to determine the independence of the results and disagreement frequencies found between extraction kits in each round, comparing them individually. Finally, to get the actual correlation between them, the kappa test was applied to two kits with smaller discrepancy between themselves in each round (KRAEMER, 1992). To calculate the Kappa coefficient, the criteria described by McGINN et al. (2004) were followed, with values greater than 0.80 representing an "almost perfect" concordance; between 0.60 and 0.80 being "substantial"; between
0.40 and 0.60 as "moderate"; and below 0.40 representing "weak" agreement.

\section{RESULTS AND DISCUSSION}

Table 2 shows the number of samples detected as positive and negative for each extraction kit evaluated. Table 3 shows the results of the McNemar test performed between all kits and the Kappa test performed on both kits with the lowest level of disagreement.

In the first round of testing results for the McNemar test were: DNeasy x Cador $\mathrm{x} 2=12.9$, DNeasy x Maxwell $16(200 \mu \mathrm{L}) \times 2=1.39$, DNeasy x Maxwell $16(400 \mu \mathrm{L}) \times 2=6.05$ and Maxwell 16 $(200 \mu \mathrm{L}) \times 16$ Maxwell $(400 \mu \mathrm{L}) \times 2=0.64$. Extraction kits with less disagreement in this round were the Maxwell $16(200 \mu \mathrm{L})$ x 16 Maxwell $(400 \mu \mathrm{L})$. However, the kappa test was conducted with the results obtained with the DNeasy kit x Maxwell 16 $(200 \mu \mathrm{L})$, because the kit with the lowest mismatch did not show better sensitivity. The value obtained for the Kappa test in the round was $\mathrm{K}=0.37$.

In the second round of testing, results for the McNemar test were DNeasy NucleoSpin $\mathrm{x}=0.75$ and $\mathrm{x}^{2}$, Analytik $\mathrm{x}$ DNeasy $\mathrm{x}^{2}=5.06$, NucleoSpin $x$ Analytik $x^{2}=0.94$. Extraction kits with less disagreement in this round were the DNeasy and Nucleospin. Kappa test was performed with the results obtained and gave $\mathrm{K}=0.64$.

In the third round of testing, results for the McNemar test were DNeasy $\mathrm{x}$ Promega $\mathrm{x}^{2}=$ 12.07, DNeasy $x$ RBC $x^{2}=0.13$, Promega $x$ RBC $x^{2}$ $=7.69$. Extraction kits with less disagreement in this round were the DNeasy and RBC. The Kappa test was performed with the results obtained and gave $\mathrm{K}=0.25$.

In the fourth round of testing, results for the McNemar test were DNeasy $\mathrm{x}$ Roche $\mathrm{x}^{2}=18.37$.

Table 1 - Oligonucleotides used in this research.

\begin{tabular}{|c|c|c|c|c|}
\hline Oligonucleotide & Oligonucleotide sequenences & $\begin{array}{l}\text { Concentration } \\
(\mathrm{nM})\end{array}$ & $\begin{array}{l}\text { Fragment } \\
\text { size (bp) }\end{array}$ & Target \\
\hline Mbo.IS1081.124.F & 5'AGGAACGCCTCAACCGAGAAG3' & 600 & \multirow{3}{*}{124} & \multirow{3}{*}{ is 1081} \\
\hline Mbo.IS1081.124.R & 5'CCTTCGATCCATTCGTCGTG3' & 600 & & \\
\hline Mbo.IS1081.124.S & 5'FAM-CGACGCCGAACCGACGTCGTC-IowaBlack1.3' & 300 & & \\
\hline Mbo.RD4.88.F & 5'CGCCTTCCTAACCAGAATTG3' & 600 & \multirow{3}{*}{88} & \multirow{3}{*}{$\begin{array}{l}\text { Region } \\
\text { Difference } 4\end{array}$} \\
\hline Mbo.RD4.88.R & 5'GGAGAGCGCCGTTGTAGG3' & 600 & & \\
\hline Mbo.RD4.88.S & 5'FAM-AGCCGTAGTCGTGCAGAAGCGCA-IowaBlack1.3' & 300 & & \\
\hline
\end{tabular}


Table 2 - Number of positive and negative samples submitted for each PCR extraction kit. 70 samples were used for each round of testing.

\begin{tabular}{|c|c|c|}
\hline \multirow{2}{*}{ Kit } & \multicolumn{2}{|c|}{-----------Results--------- } \\
\hline & Positives & Negatives \\
\hline - & & \\
\hline DNeasy & 51 & 19 \\
\hline Maxwell $16(200 \mu \mathrm{L})$ & 38 & 32 \\
\hline Maxwell $16(400 \mu \mathrm{L})$ & 39 & 31 \\
\hline Cador Pathogen & 29 & 41 \\
\hline DNeasy & 39 & 31 \\
\hline NucleoSpin TriPrep & 35 & 35 \\
\hline innuPREP DNA Mini Kit & 30 & 40 \\
\hline Dneasy & 65 & 5 \\
\hline Genomic DNA Mini Kit & 63 & 07 \\
\hline Wizard® Genomic DNA Purification & 53 & 17 \\
\hline Dneasy & 43 & 27 \\
\hline MagNA Pure LC DNA Isolation Kit II & 23 & 47 \\
\hline Dneasy & 53 & 17 \\
\hline FTA $^{\mathrm{TM}}$ Card & 51 & 19 \\
\hline
\end{tabular}

Kappa test was performed with results obtained and met $\mathrm{K}=0.28$. In the fifth round of testing results for the McNemar test were DNeasy x FTA Card $\mathrm{x}^{2}=$ 0.56 . Kappa test was performed with results obtained and gave $\mathrm{K}=0.41$.

This study evaluated and compared the performance of nine extraction kits in clinical samples with suggestive tuberculosis lesions. The use of the extract control was important to prove the efficiency of the procedures and the quality of the obtained material.

The DNeasy Blood \& Tissue Kit from QIAGEN showed better performance and sensitivity for the detection of M. bovis in comparison with the other extraction kits evaluated in all five rounds. In addition, unlike the results obtained by QUEIPOORTUÑO et al. (2008) and DURNEZ et al. (2009), cross-contamination was not observed in the extraction of DNA in the tests performed with this kit.Genomic DNA Mini Kit RBC and FTA Elute Micro Card extraction kits were the most similar to the QIAGEN kit, balanced by the number of positive samples detected.

The Genomic DNA Mini Kit, which uses no columns or the like in the centrifugation steps, performed well and with good sensitivity. According to ALDOUS et al. (2005), although DNA purification columns tend to be less conducive to contamination by inhibiting substances, the procedure does not guarantee greater efficiency of the extraction process, so it is possible to extract DNA from lesions suspected of bTB even without these columns.

The FTA Elute Micro Card proved to be a promising method for DNA extraction (if tissue is submitted to enzymatic digestion previously to impregnation), due to the convenience of sample storage cards, simple method of implementation and good sensitivity displayed by the kit, agreeing with the findings of WOLFGRAMM et al. (2009) and GONZALEZ et al. (2012). A disadvantage of the FTA is the time required for the extraction; approximately 240 minutes for 30 samples, as compared to other kits, which take 100 to 120 minutes.

Low sensitivity displayed by the other kits is probably related to the small amount of bacterial DNA present in the tissue, which difficult detection by qPCR even when extracted with a highly efficient and sensitive technique (TOMASO et al., 2010).

Despite the strong correlation observed between the RBC and DNeasy extraction kits in the third round of testing, the Kappa coefficient was low, which can be explained by the prevalence of a different distribution presented by the sum of the marginal, resulting in a relatively low Kappa, even when there is a high similarity between the tests (FEINSTEIN \& CICCHETTI, 1990). Another possibility would be the detection limit of the technique, since some samples extracted with the kit Genomic DNA Mini Kit RBC (unlike the DNeasy Blood \& Tissue) needed to be confirmed with specific primers Mbo.RD4.88, after being previously detected with the primers Mbo. is 1081.124

PCR sensitivity can still be improved. This study did not include tissue mechanical lysis by equipment like Tissue Lyzer (Qiagen, Germany) or MagNA Lyser (Roche, Germany). Mycobacterial DNA extraction from tissue is not an easy task and the use of mechanical lysis will definitely improve results obtained with any kit (COSTA et al., 2013).

\section{CONCLUSION}

The objective of this study was to evaluate nine DNA extraction methods to detect $\boldsymbol{M}$. bovis in bovine tissue. Results suggested that nucleic acid extraction kit influences deeply the diagnosis of bovine tuberculosis by qPCR in bovine tissue samples suggestive of tuberculosis lesions. 
Table 3 - Results of McNemar and Kappa tests.

\begin{tabular}{|c|c|c|}
\hline Kits & $\operatorname{McNemar}(\mathrm{ns})^{*}$ & Kappa \\
\hline Dneasy x Maxwell $16(200 \mu \mathrm{L})$ & $1.39^{* *}$ & 0.37 \\
\hline Dneasy x Maxwell $16(400 \mu \mathrm{L})$ & 6.05 & 0.36 \\
\hline Dneasy x Cador Pathogen & 12.9 & 0.21 \\
\hline Maxwell $16(200 \mu \mathrm{L})$ x Maxwell $16(400 \mu \mathrm{L})$ & $0.64^{* *}$ & 0.56 \\
\hline Dneasy x NucleoSpin TriPrep & $0.75^{* *}$ & 0.64 \\
\hline Dneasy $x$ innuPREP DNA Mini Kit & 5.06 & 0.51 \\
\hline NucleoSpin TriPrep $\mathrm{x}$ innuPREP DNA Mini Kit & $0.94^{* *}$ & 0.40 \\
\hline Dneasy x Wizard ${ }^{\circledR}$ Genomic DNA Purification & 12.07 & 0.28 \\
\hline Dneasy x Genomic DNA Mini Kit & $0.13^{* *}$ & 0.25 \\
\hline Wizard $^{\circledR}$ Genomic DNA Purification x Genomic DNA Mini Kit & 7.69 & 0.29 \\
\hline Dneasy x MagNA Pure LC DNA Isolation Kit II & 18.37 & 0.28 \\
\hline Dneasy x FTA Card & $0.56^{* *}$ & 0.41 \\
\hline
\end{tabular}

${ }^{*}$ Level of significance $5 \%$. ${ }^{* *}$ Disagreement not significant.

\section{ACKNOWLEDGEMENTS}

The authors are grateful to Laboratório Nacional Agropecuário (Lanagro-MG), INCT Pecuária and Conselho Nacional de Desenvolvimento Cientifico e Tecnológico (CNPq). SAGRES Project: 457417/2012-9 for financial support and fellowships.

\section{REFERENCES}

ALDOUS, W.K. Comparison of six methods of extracting Mycobacterium tuberculosis DNA from processed sputum for testing byquantitative real time PCR. J Clin Microbiol, v.43, p.2471-2473, 2005. Available from: <http://dx.doi. org/10.4103/0974-777X.91057>. Accessed: Mar. 02, 2016. doi: 10.4103/0974-777X.91057

BRAS IL. Ministério da Agricultura Pecuária e Abastecimento. Programa Nacional de Controle e Erradicação da Brucelose e Tuberculose - PNCEBT. [National Program for Control and Eradication of Brucellosis and Tuberculosis]. Brasil: MAPA/DAS/ DAS, 2006. 184p. Available from: <http://www.agricultura.gov.br/ arq_editor/file/Aniamal/programa $\% 20$ nacional $\% 20$ sanidade $\% 20$ brucelose/Manual\%20do\%20PNCEBT\%20-\%20Original.pdf>. Accessed: Mar. 02, 2016

BURGGRAF, S.; OLGEMÖLLER, B. Simple technique for internal control of real-time amplification assays. Clin Chem, v.50, p. 819-825, 2004. Available from: <http://www.clinchem.org/ content/50/5/819.long >. Accessed: Mar. 02, 2016. doi: 10.1373/ clinchem.2003.027961

CANEVARI-CASTELÃO, A.B. et al. Draft genome sequence of Mycobacterium bovis strain AN5, used for production of Purified Protein Derivative. Genome Announc., v. 2 p.e00277-
14, 2014. Available from: <http://www.ncbi.nlm.nih.gov/pmc/ articles/PMC3974946/>. Accessed: Mar. 02, 2016. doi: 10.1128/ genomeA.00277-14.

COSTA, P. et al. Enhanced detection of tuberculous mycobacteria in animal tissues using a semi-nested probe-based real-time PCR. PLoS One, v.11, p.e81337, 2013. Available from: <http://journals. plos.org/plosone/article?id=10.1371/journal.pone.0081337>. Accessed: Mar. 02, 2016. doi: 10.1371/journal.pone.0081337.

De La RUE-DOMMENEC, R. et al. Ante-mortem diagnosis in cattle: A review of the tuberculin tests, $\gamma$-interferon assay and other ancillary diagnostic techniques. Res Vet Sci, v.81, p.190-210, 2006. Available from: <http://www.sciencedirect.com/science/ article/pii/S0034528806000026>. Accessed: Mar. 02, 2016. doi: 10.1016/j.rvsc.2005.11.005.

DURNEZ, L. et al. A comparison of DNA extraction procedures for the detection of Mycobacterium ulcerans, the causative agent of Buruli ulcer, in clinical and environmental specimens. J Microbiol Meth, v.76, p.152-158, 2009. Available from: <http:// www.sciencedirect.com/science/article/pii/S0167701208003539>. Accessed: Mar. 02, 2016. doi: 10.1016/j.mimet.2008.10.002.

EINSTEIN, A.R.; CICCHETTI, D.V. High agreement but low kappa: I. The problems of two paradoxes. J Clin Epidemiol, v.43, p.543-549, 1990. Available from: <http://inkinghub.elsevier.com/ retrieve/pii/0895-4356(90)90158-L>. Accessed: Mar. 02, 2016. doi: 10.1016/0895-4356(90)90158.

GONZALEZ, P. et al. Evaluation of the FTA carrier device for human papillomavirus testing in developing countries. J Clin Microbiol, v.50, p.3870-3876, 2012. Available from: $<$ http://jcm. asm.org/content/50/12/3870.abstract>. Accessed: Mar. 02, 2016. doi: 10.1128/JCM.01698-12.

Ciência Rural, v.46, n.7, jul, 2016. 
HEINEMANN, M.B. et al. Bovine tuberculosis: an introduction to the aetiology, epidemiological chain, pathogenesis and clinical signs [Tuberculose bovina: uma introdução à etiologia, cadeia epidemiológica, patogenia e sinais clínicos]. Cad Tec Vet Zootec, v.59, p.1-12, 2008. Available from: <http://www.crmvmg.org.br/novoportal/ Institucional/detalheCadernoTecnico.aspx>. Accessed: Mar. 02, 2016.

KRAEMER, H.C. Evaluating medical tests. Objective and quantitative guidelines. Newbury Park (CA): Sage Publications, 1992. 296 p.

McGINN, T. et al. Tips for learners of evidence-based medicine: 3. Measures of observer variability (Kappa statistic). Can Med Assoc J, v.171, p.1369-1373, 2004. Available from: <http://www. cmaj.ca/content/171/11/1369.long>. Accessed: Mar. 02, 2016. doi: 10.1503/cmaj.1031981

NAKATANI, S.M. et al. Efficient method for mycobacterial DNA extraction in blood cultures aids rapid PCR identification of Mycobacterium tuberculosis and Mycobacterium avium. Eur J Clin Microbiol Infect Dis, v.23, p.851-854, 2004. Available from: $<$ http://link.springer.com/article/10.1007/s10096-004-1236-z>. Accessed: Mar. 02, 2016. doi: 10.1007/s10096-004-1236-z.

QUEIPO-ORTUÑO, M. et al. Comparison of seven commercial DNA extraction kits for the recovery of Brucella DNA from spiked human serum samples using real-time PCR. Eur J Clin Microbiol Infect Dis, v.27, p.109-114, 2008. Available from: $<$ http://europepmc.org/abstract/med/17973130>. Accessed: Mar. 02, 2016. doi: 10.1007/s10096-007-0409-y.
SALES, M.L. et al. Validation of a real-time PCR assay for the molecular identification of Mycobacterium tuberculosis. Braz J Microbiol, v.45, p.1362-1369, 2014. Available from: <http:// www.ncbi.nlm.nih.gov/pmc/articles/PMC4323311/>. Accessed: Mar. 02, 2016. doi: 10.1590/S1517-83822014000400029.

TOMASO, H. et al. Comparison of commercial DNA preparation kits for the detection of Brucellae in tissue using quantitative real-time PCR. BMC Infect Dis, v.10, p.100, 2010. Available from: <http://link.springer.com/article/10.1 186\%2F1471-2334-10-100>. Accessed: Mar. 02, 2016. doi: 10.1186/1471-2334-10-100.

WOLFGRAMM, E.V. et al. Simplified buccal DNA extraction with FTA elute cards. J Forensic Sci International Genetics, v.3, p.125-127, 2009. Available from: <http://www.sciencedirect. com/science/article/pii/S1872497308001853>. Accessed: Mar. 02, 2016. doi: 10.1016/j.fsigen.2008.11.008.

YOON, H.A. et al. Molecular survey of latent pseudorabies virus infection in nervous tissues of slaughtered pigs by nested and realtime PCR. J Microbiol, v.43, p.430-436, 2005.

YOSHIKAWA, $\mathrm{H}$. et al Evaluation of DNA extraction kits for molecular diagnosis of human Blastocystis subtypes from fecal samples. Parasitol Res, v.109, p.1045-1050, 2011. Available from: <http://link.springer.com/article/10.1007\%2 Fs00436-011-2342-3>. Accessed: Mar. 02, 2016. doi: 10.1007/ s00436-011-2742-4. 